\title{
EDITORIAL
}

\section{O acesso ao conhecimento como alicerce estudantil}

Sem dúvidas, o avanço tecnológico e o fomento de pesquisas trazem a todos nós uma quantidade cada vez maior de conhecimento, criando uma salutar preocupação aos profissionais da saúde em estarem atualizados. E a nós, estudantes, não se cabe diferente posição: somos incentivados a ir à fronteira do conhecimento, onde as dúvidas ainda são fortes, porém a possibilidade da acurácia científica é maior. Nesse sentido, torna-se importante meta a ampliação do acesso ao conhecimento, o qual serve como pilar para uma boa formação acadêmica de todos os graduandos.

Diariamente, são inseridas uma infinidade de informações nas bases digitais oriundas das mais diversas fontes do globo. Ter uma sólida instrução no mundo atual é, fundamentalmente, alcançá-la. Diz-se nas salas de aula que boa parte do que nos é ensinado durante a graduação médica será obsoleto quando nos formarmos. Tendo isso em vista, temos de valorizar a popularização do saber, tomando para nós da comunidade médica a missão de progredir mais e mais rumo à acessibilidade do conhecimento.

Pensando nisso, esta revista dedica-se a oferecer aos nossos leitores uma experiência de acessibilidade notável. Com poucos cliques, entra-se no site da Revista de Medicina e tem-se acesso ao arquivo de exemplares que datam até à primeira edição deste periódico, publicada em 1916. São mais de 100 anos de conhecimento científico acumulado em uma plataforma digital cujo acesso é aberto a todos os usuários da internet.

Assim, com as mentes voltadas a enaltecer a acessibilidade às informações mais recentes da área médica, é com imenso prazer que apresentamos esta edição da Revista de Medicina.

Uma ótima leitura a todos.

Bárbara Nascente Kumagai Editora-chefe da Revista de Medicina Gestão 2018 